Acta vet. scand. 1986, 27, 421—439.

From the Institute for Experimental Pathology, University of Iceland, Keldur. Reykjavik.

\title{
THE POSTPARTUM REPRODUCTIVE STATUS OF DAIRY COWS IN TWO AREAS IN ICELAND*
}

\author{
By \\ Jón Eldon and Thorsteinn ólafsson
}

\begin{abstract}
ELDON, JóN and THORSTEINN OLAFSSON: The postpartum reproductive status of dairy cows in two areas in Iceland. Acta vet. scand. 1986, 27, 421-439. - The paper describes the postpartum (pp) reproductive performance of 252 dairy cows in 2 areas in Iceland, in the north (Eyjafjörður) and in the south (Skeið), during a 12 months period.

First pp ovulation occurred significantly earlier in primiparous cows, in cows in Skeið and in cows that calved in SeptemberNovember.

The average time of first $\mathrm{pp}$ artificial insemination (ai) was 72 days in both areas. Conception rate to first ai in these cows was $58 \%$ in Eyjafjörður and $53 \%$ in Skeið and the number of ai per conception was 1.6 and 1.8, respectively. In Eyjafjörøur, $23 \%$ of the cows were inseminated at the time of first pp ovulation. Sixtytwo percent of these cows conceived. In Skeið, 20 cows were inseminated at the time of first pp ovulation, and 9 or $45 \%$ of these cows conceived. The interval from calving to conception was, on the average, 92 days in Eyjafjörour and 100 days in Skeið.

Comparison of results from individual farms showed increase in number of conceptions to first pp ai $(35-72 \%)$ and decrease in number of services per conception $(2.0-1.3)$ with increased mean number of days from calving to first ai (62-82 days).

ovulation; artificial insemination; conception; primiparous cows.
\end{abstract}

In modern dairy cow farming, female fertility is of a major economic importance (Bulman \& Lamming 1978, Janson 1980). Ideally, the time of first calving, is at 2 years of age and the ideal interval between calvings is 365 days (Britt 1975, Zeddies 1982, Haresign et al. 1983, Coleman et al. 1985). Various environmental and managerial factors affect the reproductive performance of

* This work was supported by the Icelandic Science Fund and and the International Atomic Energy Agency. 
the dairy cow (Ball 1983, Cavestany et al. 1985, Coleman et al. 1985). Common fertility problems are, for example, delayed ovulations beyond feasible insemination dates, poor oestrus detection and a low conception rate (Morrow et al. 1969, Ayalon 1984, Chauhan et al. 1984, Halpern et al. 1985).

The amount of progesterone in milk reflects the blood concentration which in turn reflects the physiological status of the ovaries (Cavestany \& Foote 1985, Hansel 1985). It has become a common practice to evaluate various reproductive factors by assaying progesterone in milk, often in connection with physical examination of the genital organs and evaluation of various blood components (Lamming \& Bulman 1976, Andresen \& Onstad 1979, Claus et al. 1983, Larsson et al. 1984).

In 1982 and 1983 we conducted a survey on the post partum (pp) fertility performance of dairy cows with fertility problems in southern Iceland. We assayed progesterone in milk sampled sequentially, examined the genital organs by rectal palpation and collected blood samples for assaying glucose, urea, calcium, magnesium and inorganic phosphate (Eldon et al. 1985). When evaluating the results, we had only results from studies on dairy cows from other countries for comparison. It was, therefore, decided to conduct a study of the postpartum reproductive performance of dairy cows on selected farms with good reproductive status in 2 areas in Iceland. The study was conducted in a similar fashion as the survey of the problem farms. The results will be used for comparison when evaluating the reproductive performance of dairy cow herds.

\section{MATERIALS AND METHODS}

Animals and study areas

The total of 252 Icelandic dairy cows on 9 farms in 2 areas were studied. Four farms were in the north of Iceland (Eyjafjörður) and 5 farms were in the south (Skeið) (Table 1).

Records of time and number of ai and time of calving were kept on the farms. All farms used ai. The cows were housed for 7-8 months in tie stalls and fed hay and feeding grain. In summer they were grased on cultivated pastures. On 2 farms, " 18 " and " 14 ", the cows were milked in a separate milking parlour. On farm " 18 ", the number of cows that fit into the milking parlour were freed from their tie stalls, milked and then tied up 
Table 1. Total number of milking cows on the farms and number of cows entering the study in the north (Eyjafjörour) and in the south (Skeið).

\begin{tabular}{|c|c|c|c|c|c|c|c|c|c|c|c|}
\hline & \multicolumn{5}{|c|}{ Eyjafjörður farms } & \multicolumn{6}{|c|}{ Skeið farms } \\
\hline & “41" & “52” & “18” & “76" & Total & “70" & "14" & “36" & “68" & "80" & Total \\
\hline Total no. of milking cows & 31 & 31 & 42 & 36 & 140 & 26 & 32 & 26 & 30 & 32 & 146 \\
\hline No. of animals in study & 31 & 31 & 39 & 33 & 134 & 14 & 30 & 18 & 25 & 31 & 118 \\
\hline
\end{tabular}

again. On farm "14" all cows to be milked were set loose at the same time and not tied up again until the milking was finished.

In Eyjafjörour, the mean temperature in January 1984 was $-5.0^{\circ} \mathrm{C}^{\star}$ and the total precipitation was $54.6 \mathrm{~mm}$. In July the mean temperature was $12.7^{\circ} \mathrm{C}$ and the total precipitation was $19.8 \mathrm{~mm}$. Hours of daylength, from sunrise to sunset, were 24 in June and 3 in December.

In Skeið, the mean temperature in January 1984 was $-3.0^{\circ} \mathrm{C}$ and the total precipitation was $85.4 \mathrm{~mm}$. In July the mean temperature was $11.1^{\circ} \mathrm{C}$ and the total precipitation was $266.5 \mathrm{~mm}$. The hours of daylength were 21 in June and 4 in December.

\section{Examination and sampling}

The genital organs were examined by rectal palpation once a month. Farm records were examined for the datas of calving, dates of ai, for number of cows slaughtered or sold and for diseases. Conception date was the date of ai after which conception was confirmed by later rectal palpation.

Sequential milk samples for progesterone profiles were taken every 5th day from day 10 postpartum until the first ai. Milk samples were also taken at the time of ai to evaluate the frequency of luteal phase inseminations. Thirty $\mathrm{ml}$ of milk were collected from each cow at the end of milking, preserved with sodium azide tablets (Merck) and stored at $4^{\circ} \mathrm{C}$ until assayed $1-2$ months after collection.

\section{Chemicals}

$\left(1,2,6,7,21-{ }^{3} \mathrm{H}\right)$-Progesterone $(195 \mathrm{Ci} / \mathrm{mmol})$ and Atomlight ${ }^{\circledR}$ scintillation fluid were purchased from New England Nuclear. The progesterone for the calibration curve was purchased from Sigma Co. The charcoal, Norit $A$, and the gelatin were purchased

\footnotetext{
* The Icelandic Meteorological Office.
} 
from Fischer Scientific Co. The Dextran T-70 came from Pharmacia Ltd. The reagents fort he phosphate buffered saline were purchased from Merck.

\section{Equipment}

${ }^{3} \mathrm{H}$-Progesterone was counted on a Packard Tri-Carb Liquid Scintillation Spectrometer Model 3330. Pipetting was carried out using Eppendorf Varipette ${ }^{\circledR}$ and Multipette $\AA$ pipettes. The centrifuge used was Beckman Model T-70. All the glassware used was Pyrex ${ }^{\circledR}$ from Corning Ltd. and the scintillation vials came from Hughes \& Hughes Ltd.

\section{Antiserum}

The antiserum* was prepared by immunizing a sheep against an 11 $\alpha$-hydroxyprogesterone-hemisuccinate conjugate. Cross-reactivity with progesterone was $100 \% ; 17 \alpha$-hydroxy-progesterone $9.5 \%$; 11 $\alpha$-hydroxyprogesterone $3.5 \%$; 11-desoxyprogesterone $3.1 \%$; 20.-dihydroxyprogesterone $1.3 \%$; other steroids, less than $1 \%$ (Castellanos \& Edqvist 1978). The antiserum was stored in small portions at $-20^{\circ} \mathrm{C}$.

\section{Progesterone assay}

Progesterone in fat free milk was assayed by a radioimmunoassay technique as reported by Oltner \& Edqvist (1980, 1981).

A $5 \mathrm{ml}$ portion from each milk sample was centrifuged at $400 \times \mathrm{g}$ for $10 \mathrm{~min}$ at $4^{\circ} \mathrm{C}$. The milk was then warmed to $37^{\circ} \mathrm{C}$ in a water bath and the fat floating on top discarded by suction. The milk was then vortex mixed.

Standards and samples were prepared in duplicate. To $100 \mu \mathrm{l}$ of fat free milk or standard were added $93 \mathrm{kBk}(10,000$ c.p.m.) tritiated progesterone in $200 \mu \mathrm{l} 0.15 \mathrm{~mol} / \mathrm{l}$ phosphate buffered saline with $0.1 \%$ gealtin (PBSG) $\mathrm{pH} 7.0$, vortex mixed and incubated for $30 \mathrm{~min}$ at $4^{\circ} \mathrm{C}$. The antiserum was added in $500 \mu \mathrm{l}$ of $0.15 \mathrm{~mol} / \mathrm{l}$ PBSG buffer. The antiserum was diluted 1:20,000 and bound $40 \%$ of the ${ }^{3} \mathrm{H}$-progesterone. After incubation for $12 \mathrm{~h}$ at $4^{\circ} \mathrm{C}, 500 \mu \mathrm{l}$ of $0^{\circ} \mathrm{C}$ charcoal-dextran suspension in 0.15 mol/l PBS buffer without gelatine was added. The samples

* The antiserum was kindly provided by Prof. Lars-Eric Edqvist, Department of Clinical Chemistry, Swedish University of Agricultural Sciences, Uppsala, Sweden. 
were then vortex mixed, incubated for $15 \mathrm{~min}$ at $4^{\circ} \mathrm{C}$ and then centrifuged at $800 \times \mathrm{g}$ and $4^{\circ} \mathrm{C}$ for $10 \mathrm{~min}$. One ml portion of the supernatant was counted in $4 \mathrm{ml}$ of scintillation fluid for $10 \mathrm{~min}$.

The standards for the calibration curve were prepared by diluting a stock progesterone solution (65 nmol/1 in $96 \%$ ethanol) to $32,16,8,4,2$ and $1 \mathrm{nmol} / \mathrm{l}$ in a fat free milk taken from a postpartum cow in oestrus and without a palpable corpus luteum. The zero standard and the non-specific-binding (NSB) sample were taken from the same milk. The milk was diluted 1:1 in a PBS buffer without gelatine before the preparation of the standards.

\section{Calculations}

The percentage of bound progesterone in the standard/sample, compared to zero standard $\left(B_{0}=100 \%\right.$ binding), was calculated, after subtracting the mean of the non-specific binding counts (NSB) from the mean counts for each standard/sample. The calibration curve of the progesterone assay was fitted by a computer to a linear logit/log curve. The log progesterone concentrations of the standards were plotted vs. their logit percent bound. The sample value was found by extrapolation of the \% bound value on the calibration curve.

Inter- and intra-assay coefficients of variation, in a milk sample with the content of $4 \mathrm{nmol} / \mathrm{l}$ of progesterone, were $27.9 \%$ and $7.4 \%$, respectively. The sensitivity of the assay was 1.1 nmol/l, average recovery was $97 \%$.

The number of days from calving to first pp ovulation were estimated by plottingt he progesterone profile. The last sample date before the progesterone curve rose above $3 \mathrm{nmol} / \mathrm{l}$ was estimated to be the date of ovulation.

Twohundred milk samples were assayed using both the method described above and a Farmos ${ }^{\circledR}$ progesterone in milk assay kit. The correlation coefficient ( $r$ ) for the comparison of the results from the two assay methods was 0.9 .

\section{Statistical analysis}

The analysis of data was carried out using a one way analysis of variance method as applied in the Minitab 82.1 software for the Vax 750 computer (Ryan et al. 1982). The natural logarithm (ln) of all values was used in the analysis. This resulted 
in the data to be more normally distributed. Variables tested were age, the interval from calving to first $\mathrm{pp}$ ovulation, the time of first pp ai and the conception. These factors were tested for significant differences between areas, all farms, farms within areas, parities, months and seasons of calving and no. of ai per conception.

\section{RESULTS}

The total number of cows studied was 252. The number of cows for which respective data was available are presented in the tables. No cow, with available data, was omitted from the data processing.

\section{Age and state of health}

The age of the cows at calving was from $2-12$ years $(\bar{x}=5.1$, years, $\mathrm{SD}=2.5$ ). In Eyjafjörour the mean age was 5.6 years $(\mathrm{SD}=2.8)$ (Table 2, Fig. 1). Seventeen percent of the cows were primiparous. Eight percent of the cows were slaughtered or sold. The oldest cows were on farm " 52 " $(\overline{\mathrm{x}}=6.8$ years, $\mathrm{SD}=3.3$ ) with $13 \%$ of the cows primiparous. The youngest cows were on farm " 41 " ( $\overline{\mathrm{x}}=4.5$ years, $\mathrm{SD}=2.1)$ with $25 \%$ of the cows primiparous. Cystic ovaries were found in 2 cows. Metritis was reported in 1 cow and 6 animals were diagnosed with clinical ketosis.

In Skeið the mean age was 4.5 years $(\mathrm{SD}=2.1$ ) (Table 2, Fig. 1). Thirtyone percent of the cows were primiparous. Twentyone percent of the cows were slaughtered or sold. The cows were oldest on farm " 68 " $(\overline{\mathrm{x}}=5.1$ years, $\mathrm{SD}=2.0)$ with

T a b l e 2. The age, in years, of the cows at calving and the percentage of primiparous cows on each farm.

\begin{tabular}{|c|c|c|c|c|c|c|c|c|c|c|c|}
\hline & \multicolumn{4}{|c|}{ Eyjafjörøur farms } & \multirow[b]{2}{*}{ Total } & \multicolumn{6}{|c|}{ Skeið farms } \\
\hline & “41" & “52" & "18" & “76" & & “70" & “14" & "36" & “68” & "80" & Total \\
\hline $\mathbf{n}$ & 28 & 30 & 33 & 33 & 124 & 14 & 22 & 18 & 24 & 31 & 109 \\
\hline$\overline{\mathbf{x}}$ age & 4.5 & 6.8 & 6.1 & 5.1 & 5.6 & 5.0 & 4.4 & 4.8 & 8. 5.1 & 13.8 & 4.5 \\
\hline SD age & 2.1 & 3.3 & 2.9 & 2.5 & 2.8 & 2.6 & 2.2 & 2.3 & 2.0 & 1.5 & 2.1 \\
\hline Min. age & 2.0 & 2.3 & 2.0 & 1.8 & 1.8 & 2.0 & 2.3 & 2.0 & 2.3 & 2.0 & 2.0 \\
\hline Max. age & 9.9 & 12.0 & 12.4 & 11.9 & 12.4 & 8.5 & 10.1 & 8.7 & 8.8 & 7.6 & 10.1 \\
\hline Primiparous & & & & & & & & & & & \\
\hline cows $(\%)$ & 25 & 13 & 18 & 12 & 17 & 29 & 45 & 22 & 21 & 36 & 31 \\
\hline
\end{tabular}



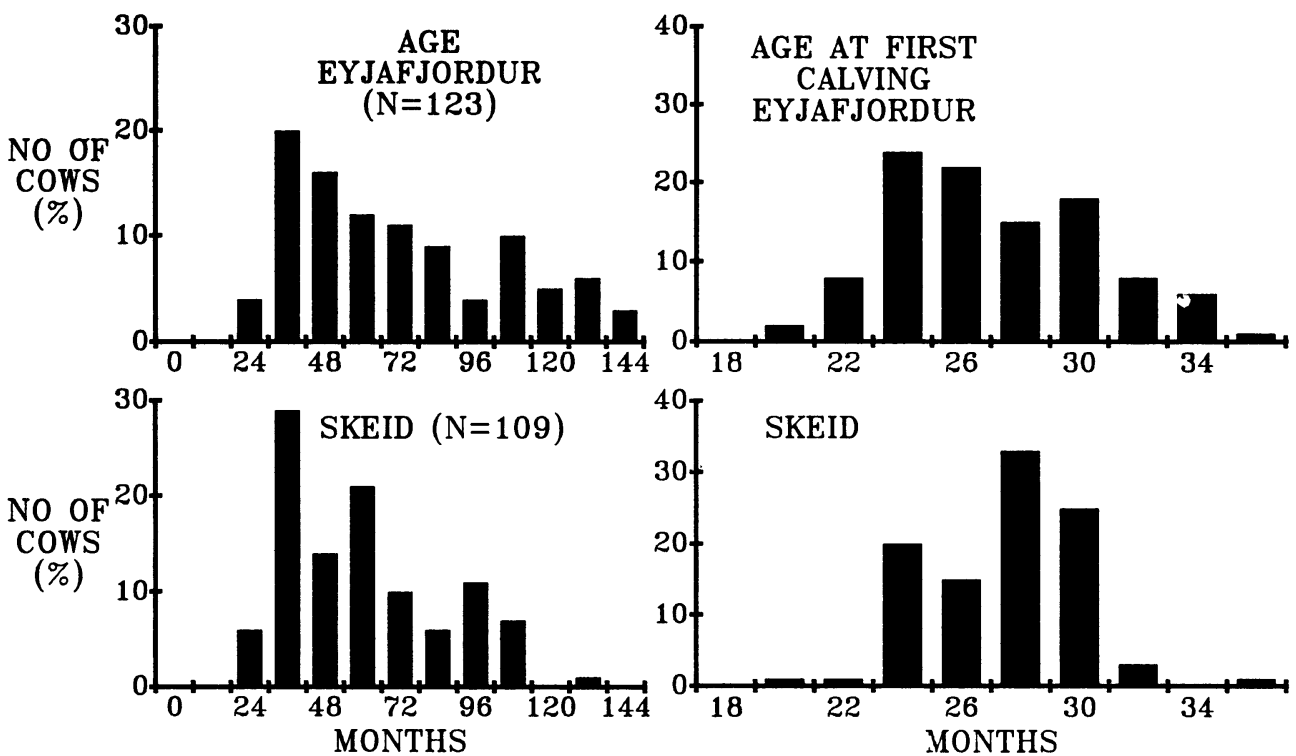

Figure 1. The frequency distribution of the age of the cows on the calving date, and the age at first calving, in months.

T a b le 3. The levels of significance from the analysis of variance; $(\mathrm{ns})=$ not significant $(\mathrm{P}>0.05) ;\left({ }^{*}\right)=(\mathrm{P}<0.05),{\left({ }^{\star}{ }^{\star}\right)}_{(\mathrm{P}<0.01)}$,

$$
\left({ }^{\star \star \star}\right)=(\mathrm{P}<0.001) \text {. }
$$

\begin{tabular}{|c|c|c|c|c|c|c|c|c|c|}
\hline \multirow[b]{2}{*}{ Category } & \multicolumn{9}{|c|}{ Source of variation } \\
\hline & 1 & 2 & 3 & 4 & 5 & 6 & 7 & 8 & 9 \\
\hline $\mathbf{A}$ & * & * & * & * & * & nis & $\star \star \star$ & $\star \star \star \star$ & ns \\
\hline B & ns & $\star \star$ & $\star \star \star$ & * & nis & $\mathbf{n}_{\mathbf{S}}$ & ns & ns. & * \\
\hline $\mathbf{C}$ & ns & nis & ns & * & $\mathrm{ns}$ & $\star \star \star$ & ns & ns & $\star \star$ \\
\hline D & $\star \star \star$ & $\star \star \star \star$ & * & * & - & - & ns & ns & ns \\
\hline
\end{tabular}
A: Time of first pp ov
B: Time of first pp ai
C: Time of conception
D: Age

1: Area

2: All farms

3: Eyjafjörøur farms

4: Skeið farms

5: Primiparous vs. multiparous

6: Cows conceiving to first ai vs. rest of cows

7: Month of calving

8: Season of calving

9: No. of ai per conception 
$21 \%$ of primiparous cows and youngest on farm " 80 " $(\overline{\mathrm{x}}=3.8$ years, $\mathrm{SD}=1.5$ ) with $36 \%$ of first calves. Cystic ovaries were discovered in 4 cows. Retained placenta and metritis was reported in 3 cows and 16 developed clinical ketosis.

The difference in age between areas and between farms was statistically significant $(\mathrm{P}<0.01)$ (Table 3 ).

\section{Calving}

The cows calved all year round. In Eyjafjörður most of the calvings were in March-May. In Skeið the calvings were more evenly distributed throughout the year (Fig. 2). Forty seven percent of all primiparous cows calved in September-November. Primiparous cows were $48 \%$ of all cows that calved during this period.

The mean age at first calving was 27 months in both areas (Fig. 1). This age was lowest 24 months $(\mathrm{SD}=2.1$ ) on farm “76" and highest 29 months ( $\mathrm{SD}=3.2$ ) on farm "18". This difference was statistically significant $(\mathrm{P}<0.01)$.
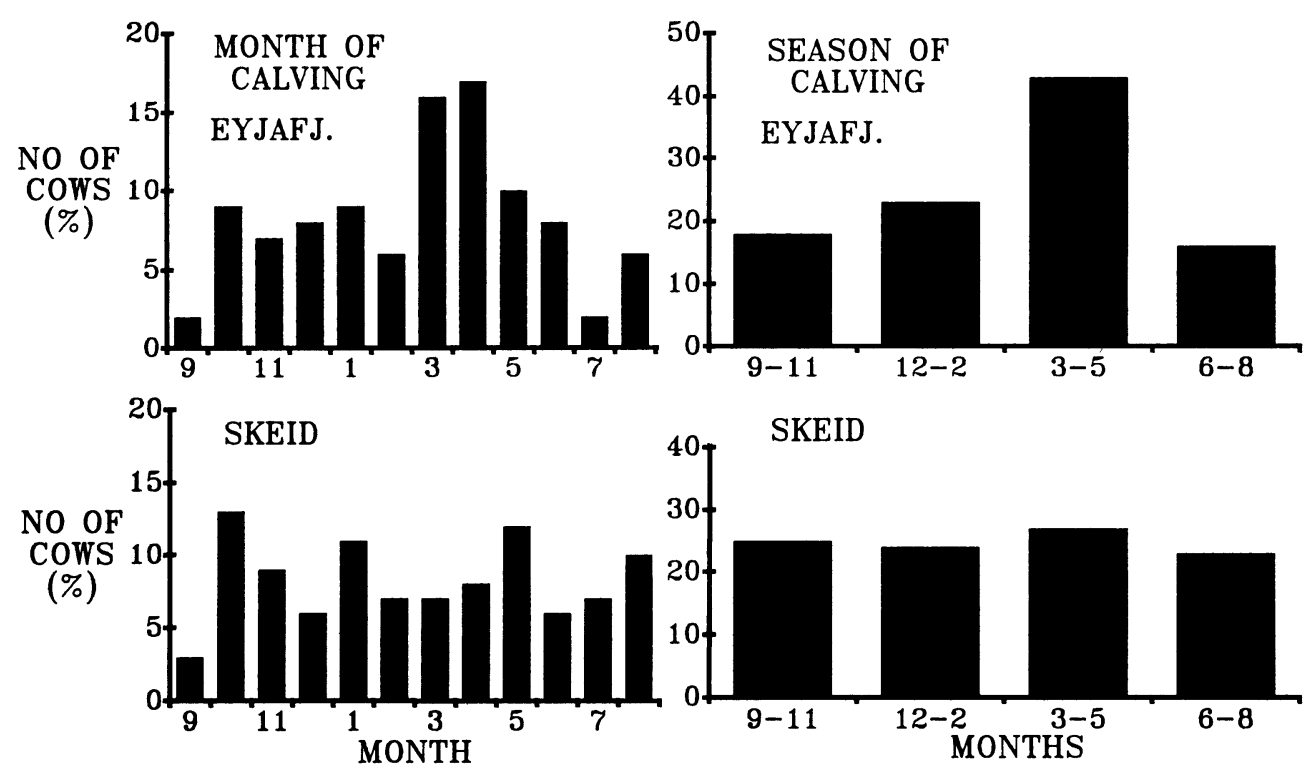

Fig u re 2. The frequency distribution of the number of cows calving in each month and in each season. 


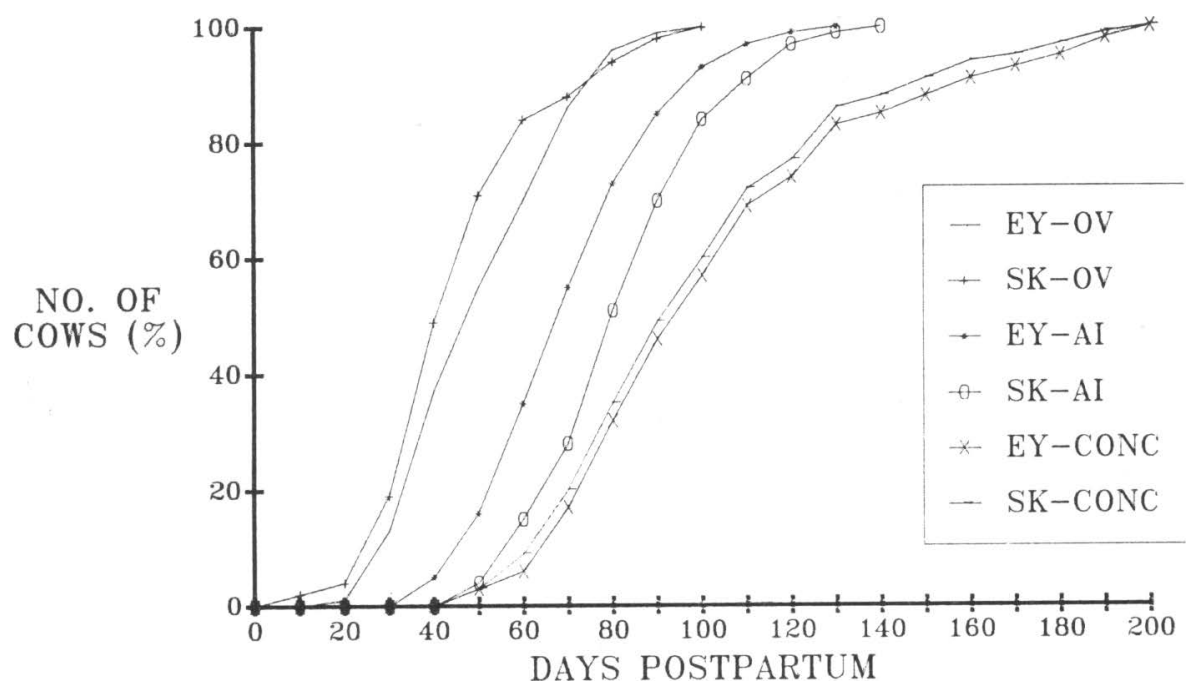

Figure 3. Time of the first pp ovulation, the first pp ai and the conception in Eyjafjörður and in Skeið. Cumulative no. of cows (\%).

\section{Ovulation}

In Eyjafjörður, first pp ovulation was, on the average, 42 days $(\mathrm{SD}=20.6$ ) after calving. The range of means, for the individuals farms, was $35-58$ days (Table 4 , Fig. 3 ).

In Skeið, first pp ovulation was, on the average, 37 days ( $\mathrm{SD}=21.7$ ) after calving. The range of means, for the individual farms, was $29-52$ days (Table 4 , Fig. 3 ).

The difference in mean number of days from calving to first

Table 4. The interval from calving to first postpartum ovulation and the number of days from parturition until 50, 75 and $90 \%$ of the cows had ovulated.

\begin{tabular}{|c|c|c|c|c|c|c|c|c|c|c|c|}
\hline & \multicolumn{4}{|c|}{ Eyjafjörður farms } & \multirow[b]{2}{*}{ Total } & \multicolumn{6}{|c|}{ Skeiס farms } \\
\hline & "41" & "52" & “18" & “76" & & “70" & “14" & “36”。 & “68” & $" 80 "$ & Total \\
\hline $\mathbf{n}$ & 27 & 30 & 36 & 32 & 125 & 13 & 29 & 18 & 23 & 30 & 113 \\
\hline$\overline{\mathbf{x}}$ days & 35 & 45 & 46 & 58 & 42 & 43 & 29 & 52 & 33 & 38 & 37 \\
\hline SD days & 15.1 & 26.9 & 18.7 & 18.1 & 20.6 & 24.8 & 18.2 & 29.4 & $\begin{array}{l}17.8 \\
\quad 17\end{array}$ & 818.7 & 21.7 \\
\hline Min. days & 12 & 12 & 10 & 18 & 10 & 11 & 7 & 17 & 11 & 9 & 7 \\
\hline Max. days & 68 & 133 & 80 & 95 & 133 & 104 & 102 & 144 & 75 & 86 & 144 \\
\hline \multicolumn{12}{|l|}{ Percentiles: } \\
\hline 50 & 30 & 39 & 34 & 60 & 39 & 39 & 25 & 48 & 28 & 33 & 32 \\
\hline 75 & 45 & 54 & 48 & 69 & 55 & 45 & 33 & 68 & 43 & 45 & 45 \\
\hline 90 & 54 & 58 & 66 & 81 & 66 & 83 & 39 & 72 & 62 & 64 & 66 \\
\hline
\end{tabular}


pp ovulation between farms within areas and between areas was statistically significant (Table 3 ).

Primiparous cows ovulated earlier pp $(\overline{\mathrm{x}}=39$ days, $\mathrm{SD}=$ 27.5) than did multiparous cows $(\overrightarrow{\mathrm{x}}=42$ days, $\mathrm{SD}=18.5)$. The difference was statistically significant $(P<0.05)$ (Table 3 ). There was a negative correlation between the relative number of primiparous cows o neach farm and the mean number of days from calving to first $\mathrm{pp}$ ovulation $(\mathrm{y}=-0.6 \mathrm{x}+57, \mathrm{r}=-0.7$ ).

Cows calving in September-November ovulated, on the average, 30 days pp $(\mathrm{SD}=20.1)$. Cows calving other months of the year ovulated, on the average, 43 days $\mathrm{pp}(\mathrm{SD}=20.6)$ (Fig. 4). This difference was statistically significant $(P<0.01)$ (Table 3).
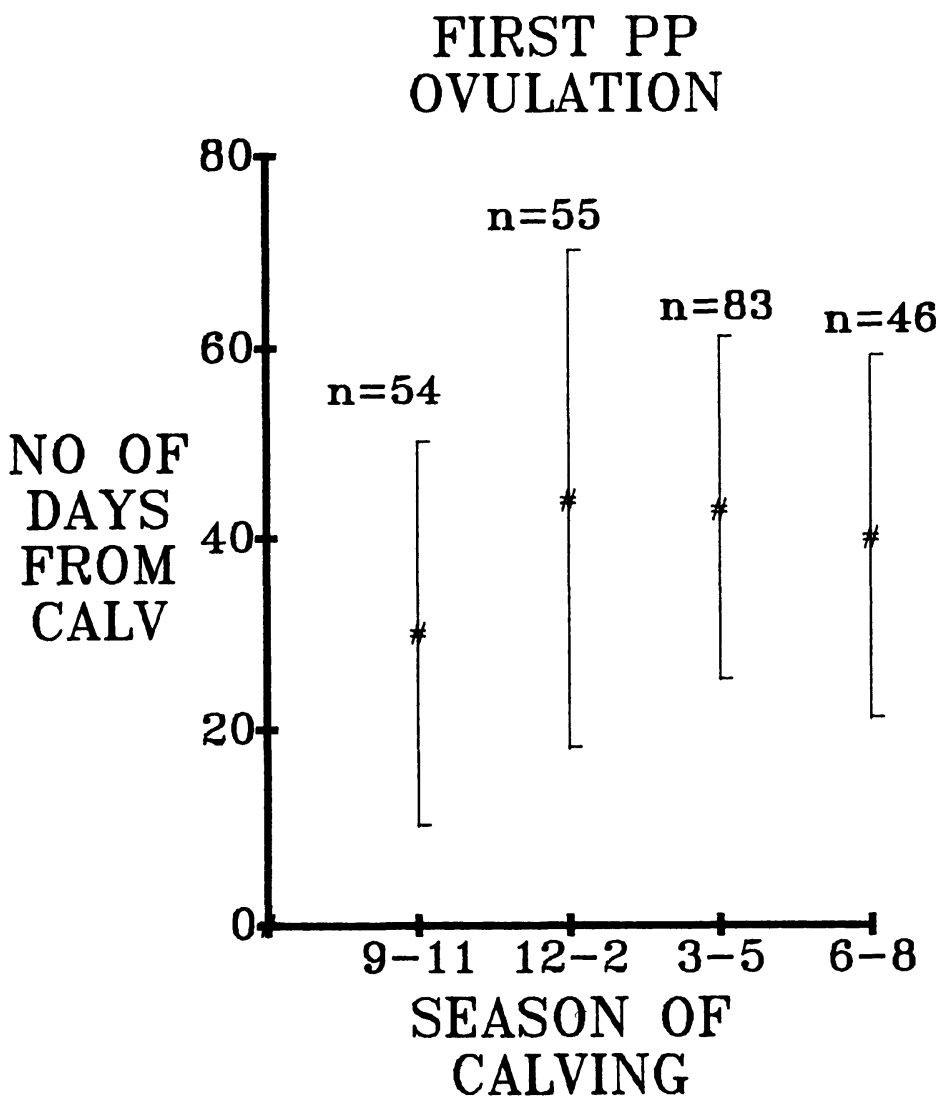

Figure 4. The time of the first $p p$ ov \pm 1 SD for both areas combined, in relation to the month and season of calving (months). 
The mean length of the first pp ovarian cycle of 173 cows was 16 days ( $S D=4.4$ ) and the mean of the highest progesterone values measured was $8 \mathrm{nmol} / \mathrm{l}(\mathrm{SD}=4.5)$. The mean length of the second ovarian cycle of 88 cows was 20 days $(\mathrm{SD}=2.5$ ) and the mean of the highest progesterone values assayed was $9 \mathrm{nmol} / \mathrm{l}(\mathrm{SD}=4.2)$. The first pp ovarian cycle was $\leq 15$ days in $57 \%$ of the cows. The total mean of the highest progesterone values of the cycles that were $\leq 15$ days in lenght, were $8 \mathrm{nmol} / \mathrm{l}(\mathrm{SD}=3.9$ ) and of the cycles that were $>15$ days, $10 \mathrm{nmol} / \mathrm{l}(\mathrm{SD}=4.9)$. This difference was statistically significant $(\mathrm{P}<0.05)$.

\section{AI}

In Eyjafjörður the interval from calving to first pp ai was, on the average, 72 days $(S D=23.1)$. The range of means, for the individual farms, was $61-82$ days (Table 5, Fig. 3 ).

Twelve percent of the cows in Eyjafjörour had been inseminated (first pp ai) when progesterone in milk was more than $3 \mathrm{nmol} / 1$.

In Skeið, the interval from calving to first pp ai was the same as in Eyjafjörður, 72 days $(\mathrm{SD}=22.6)$. The range of means was $64-83$ days (Table 5, Fig. 3 ).

Five percent of the cows in Skeið had been inseminated when progesterone in milk was $>3 \mathrm{nmol} / \mathrm{l}$.

The difference in number of days from calving to first pp ai between farms within areas was statistically significant $(\mathrm{P}<0.05$ ) ('Table 3).

T a b l e 5. The interval from parturition to first pp ai and the number of days from calving when 50,75 and $90 \%$ of the cows had been inseminated (first pp ai).

\begin{tabular}{|c|c|c|c|c|c|c|c|c|c|c|c|}
\hline & \multicolumn{4}{|c|}{ Eyjafjörøur farms } & \multirow[b]{2}{*}{ Total } & \multicolumn{6}{|c|}{ Skeið farms } \\
\hline & “41" & "52" & "18" & “76" & & “70" & "14" & “36" ‘ & “68” & "80" & Total \\
\hline $\mathbf{n}$ & 27 & 28 & 37 & 32 & 124 & 11 & 27 & 18 & 24 & 30 & 110 \\
\hline$\overline{\mathbf{x}}$ days & 73 & 61 & 82 & 69 & 72 & 83 & 76 & 77 & 64 & 68 & 72 \\
\hline SD days & 20.9 & 16.7 & 25.0 & 15.5 & 23.1 & 22.4 & 16.1 & 30.7 & 21.7 & 721.8 & 22.6 \\
\hline Min. days & 40 & 34 & 40 & 46 & 34 & 54 & 47 & 44 & 17 & 40 & 17 \\
\hline Max. days & 118 & 112 & 150 & 100 & 150 & 128 & 109 & 144 & 100 & 147 & 147 \\
\hline \multicolumn{12}{|c|}{ Percentiles: } \\
\hline 50 & 73 & 59 & 79 & 70 & 69 & 80 & 77 & 68 & 66 & 67 & 69 \\
\hline 75 & 90 & 71 & 94 & 80 & 84 & 90 & 84 & 97 & 81 & 74 & 84 \\
\hline 90 & 96 & 78 & 110 & 89 & 99 & 106 & 97 & 113 & 91 & 89 & 101 \\
\hline
\end{tabular}


T a b l e 6. The interval from parturition to conception and the number of days from calving, when 50, 75 and $90 \%$ of the cows had conceived the rate to first ai and the number of ai per conception.

\begin{tabular}{|c|c|c|c|c|c|c|c|c|c|c|c|}
\hline & \multicolumn{5}{|c|}{ Eyjafjörøur farms } & \multicolumn{6}{|c|}{ Skeið farms } \\
\hline & “41" & “52" & "18" & “76" & Total & “70" & "14" & “36" & “68" & “80" & Total \\
\hline $\mathbf{n}$ & 24 & 25 & 32 & 31 & 112 & 11 & 27 & 17 & 22 & 29 & 106 \\
\hline$\overline{\mathbf{x}}$ days & 94 & 95 & 99 & 81 & 93 & 120 & 86 & 115 & 92 & 106 & 100 \\
\hline SD days & 44.0 & 54.2 & 44.7 & 27.4 & 42.7 & 55.0 & 21.9 & 943.8 & 838.9 & 940.9 & 39.1 \\
\hline Min days & 46 & 34 & 51 & 46 & 34 & 62 & 47 & 44 & 43 & 40 & 40 \\
\hline Max. days & 222 & 249 & 265 & 157 & 265 & 208 & 140 & 179 & 181 & 189 & 208 \\
\hline \multicolumn{12}{|l|}{ Percentiles } \\
\hline 50 & 76 & 75 & 87 & 85 & 82 & 98 & 84 & 112 & 84 & 94 & 89 \\
\hline 75 & 111 & 115 & 111 & 94 & 111 & 156 & 99 & 155 & 102 & 138 & 124 \\
\hline 90 & 143 & 174 & 150 & 118 & 150 & 201 & 109 & 175 & 144 & 161 & 161 \\
\hline Conception to first ai (\%) & 68 & 35 & 71 & 55 & 58 & 50 & 72 & 41 & 52 & 44 & 53 \\
\hline No. of ai per conception & 1.4 & 2.0 & 1.3 & 1.6 & 1.6 & 1.8 & 1.4 & 2.1 & 1.7 & 2.1 & 1.8 \\
\hline
\end{tabular}

\section{Conception}

The interval from calving to conception in Eyjafjörour was, on the average, 93 days $(S D=42.7)$. The range of means, for the individual farms, was $81-99$ days (Table 6, Fig. 3 ).

Conception to first ai in Eyjafjörour was $58 \%$ and the number of inseminations per conception was 1.6. The conception rate to first ai was a high $71 \%$ with 1.3 ai per conception and a low $35 \%$ with 2.0 ai per conception (Table 6 ).

Twentythree percent of the cows in Eyjafjörour were inseminated at the time of first pp ovulation $(\bar{x}=57$ days, $\mathrm{SD}=$ 11.8). Sixtytwo percent of these cows conceived to that service.

In Skeid, the interval from calving to conception was 100 days $(\mathrm{SD}=39.1$ ). The range of means was $86-120$ days (Table 6, Fig. 3).

Conception rate to first ai was $53 \%$ and the number of ai per conception was 1.8. The conception rate to first ai was a high $72 \%$ with 1.4 ai per conception and a low $41 \%$ with 2.1 ai per conception (Table 6 ).

Seventeen percent of the cows in Skei $\delta$ were inseminated at the time of first $\mathrm{pp}$ ovulation $(\overline{\mathrm{x}}=66$ days, $\mathrm{SD}=28.4)$. Fortyfive percent of these cows conceived to that service.

In both areas the conception rate to first ai increased (35$72 \%)$ and the number of ai per conception decreased (2.0-1.3) with increasing mean number of days from calving to first pp ai (62-82 days). 
The number of ai per conception did not change with age, nor was there any difference in conception rate between primiparous and multiparous cows. There was no relationship between the number of days from calving to first pp ov and the number of ai per conception. There was no significant difference in mean number of days from calving to conception between areas nor between farms in Eyjafjörour, but there was a significant difference between farms in Skeið $(P<0.05)$ (Table 3 ).

\section{DISCUSSION}

The mean age of the cows in Skeið was significantly lower than in Eyjafjörour (4.5 vs. 5.1 years). The number of primiparous cows was higher in Skeið (31\% vs. $17 \%$ ) and also the number of cows slaughtered or sold. The mean age at first calving was the same in both areas, 27 months. The mean age of 31,000 dairy cows in Sweden was 3.7 years and the number of primiparous cows was $31 \%$ (Janson 1980). The mean age at first calving for 24,000 Swedish dairy cows was 29.7 months (SHS Report 1985). Coleman et al. (1985) reported 4.6 years as average age and 29 months as average age at first calving for 19 dairy cow herds in Western Virginia, USA.

The frequency of diseases of the genital organs was low. Cystic ovaries were found in 2 cows in Eyjafjörour and in 4 cows in Skeið. In a survey done on dairy cows on farms in southern Iceland, no ovarian cysts were found (Eldon et al. 1985). Larsson et al. (1984) found ovarian cysts in $11 \%$ of 291 Swedish dairy cows. Roine \& Saloniemi (1978) reported that ovarian cysts had been diagnosed in $4.1 \%$ of 2300 Finnish dairy cows. Coleman et al. (1985) found ovarian cysts in $9.7 \%$ of 2500 dairy cows in Western Virginia.

Clinical ketosis was reported in 6 cows in Eyjafjörður and in 16 cows in Skeið. This disorder was reported in $35 \%$ of dairy cows on problem farms in southern Iceland (Eldon et al. 1985). Hyperketonaemia was found in $8.9 \%$ of 3000 Swedish dairy cows during the first month after parturition (Andersson \& Emanuelsson, submitted).

The mean number of days from parturition to first pp ov was significantly lower in Skeið than in Eyjafjörður (37 vs. 43 days). This period was 40 days in cows on farms in southern Iceland (Eldon et al. 1985). Larsson et al. (1984) reported this 
interval to be 26.5 days in 291 Swedish dairy cows. Bulman \& Lamming (1978) reported that 535 Friesian and Ayrshire dairy cows in England had resumed cycles, on the average, 24 days pp. Morrow et al. (1969) reported that in most cows the interval from parturition to first $\mathrm{pp}$ ov in 85 normal cows was 15 days.

The farm in each area that had the greatest number of primiparous cows (" 41 " and " 14 "), had the shortest average interval from calving to first $\mathrm{pp}$ ovulation and the highest conception rate. Rosenberg et al. (1977) found that the interval from parturition to the first pp progesterone peak was significantly longer in primiparous cows. Larsson et al. (1984) found that parity was not significant for time of first pp ovulation.

On farm "14" the cows were set free from the tie stalls twice a day during the milking period. Claus et al. (1983) found that acyclia was significantly longer in cows housed in tie stalls as compared with cows housed in loose housing. On the other hand, King et al. (1976) reported that oestrus was detected significantly later in cows housed in free stalls compared to tie stalls.

Cows that calved in September-November ovulated significantly earlier than cows that calved in other months. Fortyeight percent of these cows were primiparous. During these 3 months the cows were probably on a high nutritional plateau after grasing all summer on cultivated pastures. The difference in the number of daylight hours could possibly have played a part in the difference in onset of cyclicity between seasons and between areas. Bulman \& Lamming (1978) found that the interval from parturition to first $\mathrm{pp}$ ovulation varied significantly with season. McNatty et al. (1984) stated that this period is shorter in a long photoperiod due to seasonal difference in gonadotropin secretion. Montgommery et al. (1985) stated that season of calving influenced resumption of ovarian cycles and that the nutrition before and after parturition influenced the interval from calving to oestrus.

The length of the first and second ovarian cycles, the number of short cycles and the amount of porgesterone in milk assayed during those cycles were in agreement with the findings of other authors (Mather et al. 1978, Kindahl et al. 1982, Williams et al. 1983, Edqvist et al. 1984, Larsson et al. 1984, Eldon et al. 1985).

The interval from parturition to first $\mathrm{pp}$ ai was, on the averrage, $60-80$ days $p$. This interval was $74-78$ days $p p$ for cows 
in southern Iceland (Eldon et al. 1985). Britt (1975) stated that cows must conceive by 85 days pp to deliver the next calf within a year. Larsson et al. (1984) reported the average interval from parturition to first pp ai as 67.2 days.

Luteal phase inseminations were $12 \%$ in Eyjafjörður and $5 \%$ in Skeið. The same figure was $20 \%$ on problem farms in southern Iceland (Eldon et al. 1985). The incidence of luteal phase inseminations in this study is similar to the findings of Hoffmann et al. (1976), Andresen \& Onstad (1979), Oltner \& Edqvist (1981) and Claus et al. (1983) for normal cows.

The interval from parturition to conception was, on the average, $80-120$ days pp, which makes the average calving interval $367-407$ days. The conception rate to first ai was $58 \%$ in Eyjafjörður and $53 \%$ in Skeið. The conception rate to first ai in cows in southern Iceland was $49 \%$ (Eldon et al. 1985). Larsson et al. (1984) reported that the average interval from parturition to conception in a herd of Swedish dairy cows was 95.3 days. Janson (1980) reported that the mean interval from parturition to last insemination for a large number of Swedish dairy cows was 103 days, the conception rate to first service was $55 \%$. Larsson et al. (1984) reported an average interval from calving to conception of 95.3 days. Reimers et al. (1985) found a $59 \%$ conception rate to first pp ai in 4500 dairy cows in the northeastern United States.

Conception rate increased and the number of ai per conception decreased with increasing number of days from parturition to first pp ai. In contrast, cows in Eyjafjörour, that were inseminated during first pp oestrus ( $\bar{x}=57$ days $p p)$, had a higher conception rate $(62 \%)$ than the average for that area. Britt (1975) stated that there was an inverse relationship between interval to first insemination and number of inseminations per conception. Larsson et al. (1984) reported a low conception rate to early inseminations.

On farms " 52 " and "18" the interval from parturition to first pp ov was similar. The interval from parturition to first pp ai was 61 and 82 days, respectively and the number of ai per conception was 2.0 and 1.3 , respectively. This led to similar results, concerning time of conception ( $\bar{x}=95$ vs. 99 days), in spite of 21 days difference in mean time of first pp ai.

The results indicate that the reproductive performance of normal Icelandic dairy cows is similar to that of Swedish dairy 
cows in spite of later onset of $\mathrm{pp}$ ovarian activity. The most significant factors affecting the interval from parturition to first pp ovulation were month of calving and the number of primiparous cows. The most significant factor affecting the time from parturition to conception was the time of first pp ai which in turn affected the conception rate to first ai and the number of ai per conception. The frequencies of luteal phase inseminations and diseases of the genital organs were too low to be of importance.

\section{ACKNOWLEDGEMENT}

We thank Dr. H. Kindahl at the Department of Obstetrics and Gynaecology, Swedish University of Agricultural Sciences, for reviewing the manuscript, Dr. H. Thorsson at the Computing Services, University of Iceland, for his assistance in the statistical analysis and Mr. G. Steindórsson for his assistance on the farm. The study was supported by the International Atomic Energy Agency and the Icelandic Science Fund.

\section{REFERENCES}

Anderson, L. U. Emanuelson: An epidemiological study of hyperketonaemia in Swedish dairy cows; determinants and the relation to fertility. Submitted for publication.

Andresen, $\emptyset$. \& O. Onstad: Brunstkontroll og drektighetskontroll hos ku ved hjelp av progesteron bestemmelse i melk (Control of oestrus and conception with the help of progesterone assay in milk). Norsk Vet.-Tidskr. 1979, 91, 411-421.

Ayalon, N.: The repeat breeder problem. Vlaams Diergeneeskundig Tijdschrift. 1984, 53, 230—239.

Ball, P.: Fertility problems in dairy herds. In Practice 1983, 5, 189194.

Britt, J. H.: Early postpartum breeding in dairy cows: A review. J. Dairy Sci. 1975, 58, 266-271.

Bulman, D. C. \& G. E. Lamming: Milk progesterone levels in relation to conception, repeat breeding and factors influencing acyclicity in dairy cows. J. Reprod. Fert. 1978, 54, 447-458.

Castellanos, R. \& L.-E. Edqvist: Evaluation of radioimmunoassay tehcnique for the measurement of progesterone. Stencil. Dept. of Clinical Chemistry, Swedish University of Agricultural Sciences (SLU), Uppsala, Sweden 1978, p. 1-27.

Cavestany, $D . \& R$. H. Foote: The use of milk progesterone and electronic vaginal probes as aids in large dairy herd reproductive management. Cornell Vet. 1985, 75, 441-453.

Cavestany, D., A. B. El-Wishy \& R. H. Foote: Effect of season and high environmental temperature on fertility of Holstein cattle. J. Dairy Sci. 1985, 68, 1471-1478. 
Chauhan, F. S., F. O. K. Mgongo \& B. M. Kessy: Recent advances in hormonal therapy of bovine reproductive disorders: A review. Vet. Bull. 1984, 54, 991-1009.

Claus, R., H. Karg, I. Zwiauer, I. von Butler, F. Pirchner \& E. Rattenberger: Analysis of factors influencing reproductive performance of the dairy cow by progesterone assay in milk-fat. Brit. vet. J. 1983, 139, $29-37$.

Coleman, D. A., W. V. Thayne \& R. A. Dailey: Factors affecting reproductive performance of dairy cows. J. Dairy Sci. 1985, 68, $1793-1803$.

Edqvist, L.-E., G. Fredriksson, H. Kindahl, K. Larsson \& A. Madej: Short oestrous cycles post partum in cattle. In: "The use of nuclear technique to improve dometsic buffalo production in Asia”. International Atomic Energy Agency, Vienna 1984, p. $79-83$.

Eldon, J., Th. Olafsson \& Th. Thorsteinsson: A survey of the postpartum reproductive performance of dairy cows with fertility problems in southern Iceland. Acta vet. scand. 1985, 26, 431441.

Halpern, N. E., H. N. Erb \& R. D. Smith: Duration of retained fetal membranes and subsequent fertility in dairy cows. Theriogenology 1985, 23, 807-813.

Hansel, W.: Advances in physiology of growth, reproduction and lactation. Cornell Vet. 1985, 75, 56-76.

Haresign, W., G. R. Foxcroft \& G. E. Lamming: Control of ovulation in farm animals. J. Reprod. Fert. 1983, 69, 383-395.

Hoffmann, B., O. Günzler, R. Hamburger \& W. Schmidt: Milk progesterone as a parameter for fertility control in cattle; methodological approaches and present status of application in Germany. Brit. vet. J. 1976, 132, 469-476.

Janson, L.: Studies on fertility traits in Swedish dairy cattle. Acta Agric. scand. 1980, 30, 109-124.

Kindahl, H., L.-E. Edqvist, K. Larsson \& A. Malmqvist: Influence of prostaglandins. In: "Factors Influencing Fertility in the Postpartum Cow”. (eds. H. Karg \& E. Schallenberger), Martinus Nijhoff Publishers, The Hague, Current Topics in Veterinary Medicine and Animal Science 1982, 20, 173-196.

King, G. J., J. F. Hurnik \& H. A. Robertson: Ovarian function and estrus in dairy cow during early lactation. J. Anim. Sci. 1976, $42,688-692$.

Lamming, G. E. \& D. C. Bulman: The use of milk progesterone radioimmunoassay in the diagnosis and treatment of subfertility in dairy cows. Brit. vet. J. 1976, 132, 507-517.

Larsson, K., L. Janson, B. Berglund, L.-E. Edqvist \& H. Kindahl: Postpartum reproductive performance in dairy cows. $I$. Influence of animal breed and parity. Acta vet. scand. 1984, 25, 445-461.

Mather, E. C., P. M. Camper, F. Vahdat, H. L. Whitmore \& B. G. Gustafsson: Assessment of ovarian activity in the postpartum 
dairy cow by use of milk porgesterone assay. Theriogenology 1978, 10, 119-129.

McNatty, K. P., N. Hudson, M. Gibb, K. M. Henderson, S. Lun, D. Hearth \& G. W. Montgomery: Seasonal differences in ovarian activity in cows. J. Endocr. 1984, 102, 189-198.

Montgomery, G. W., I. C. Scott \& N. Hudson: An interaction between season of calving and nutrition on the resumption of ovarian cycles in postpartum beef cattle. J. Reprod. Fert. 1985, 73, 4550.

Morrow, D. A., S. J. Roberts \& K. McEntee: Postpartum ovarian activity and involution of the uterus and cervix in dairy cattle. I. Ovarian activity. Cornell Vet. 1969, 59, 173-190.

Oltner, R. \& L.-E. Edqvist: Progesteron i mjölk (Progesterone in milk). In: "Progesteron i mjölk". SHS Communication no. 101, 1980, p. $4-28$.

Oltner, R. \& L.-E. Edqvist: Progesterone in defatted milk: Its relation to insemination and pregnancy in normal cows as compared with cows on problem farms and in individual problem animals. Brit. vet. J. 1981, 137, 78-87.

Reimers, T. J., R. D. Smith \& S. K. Newman: Management factors affecting reproductive performance of dairy cows in the Northeastern United States. J. Dairy Sci. 1985, 68, 963-972.

Roine, $K . \& H$. Saloniemi: Incidence of infertility in dairy cows. Acta vet. scand. $1978,19,354-367$.

Rosenberg, M., Z. Herz, M. Davidson \& Y. Folman: Seasonal variations in post-partum plasma progesterone levels and conception in primiparous and multiparous dairy cows. J. Reprod. Fert. 1977, $51,363-367$.

Ryan Jr., T. A., B. A. Joiner \& B. A. Ryan: Minitab Reference Manual. 1982, Nov. 1. Copywright Thomas A. Ryan 1982.

SHS (Association for Swedish Livestock Breeding and Production): Annual Report 1985, p. 1-139.

Williams, G. L., F. Talavera, B. J. Petersen, J. D. Kirsch \& J. E. Tilton: Coincident secretion of follicle-stimulating hormone and luteinizing hormone in early postpartum beef cows: Effects of suckilgn and low-level increase of systematic progesterone. Biol. Reprod. 1983, 29, 362-373.

Zeddies, J.: Special economic aspects of fertility related to Central European farming conditions. In: "Factors Influencing Fertility in the Postpartum Cow" (eds. H. Karg \& E. Schallenberger), Martinus Nijhoff Publishesr, The Hague, Current Topics in Veterinary and Animal Science 1982, 20, 425-441.

\section{SAMMANFATTNING}

Reproduktionsstatus postpartum hos mjölkkor i två områden på Island.

Artikeln beskriver reproduktionsstatus postpartum (pp) hos 252 mjölkkor i två områden på Island, i norra (Eyjafjörður) och i södra (Skeið) delen av Island, över en 12 månaders period. 
Första ovulationen pp förekom tidigare hos primipara kor i Skeið̈-området och hos kor som kalvade i September-November.

Tiden för första artificiella inseminationen (ai) var i genomsnitt 72 dagar. Dräktigheten efter första ai hos dessa kor var $58 \%$ i Eyjafjörður och $53 \%$ i Skeið, och antal ai per dräktighet var 1.6 respektive 1.8. I Eyjafjörður blev $23 \%$ av korna inseminerade vid första ovulationen och $62 \%$ av dessa blev dräktiga. I Skeið blev $20 \%$ av korna inseminerade vid första ovulationen och $45 \%$ blev dräktiga.

Intervallet från kalvning till dräktighet var i genomsnitt 92 dagar i Eyjafjörður och 100 dagar i Skeið.

Vid jämförelse av resultat från enstaka gårdar visade en ökning i antal dräktigheter till första ai (35 till $72 \%$ ) och minskning i antal ai (2.0 till 1.3) med ökad antal dagar från kalvning till första ai (62-82 dagar).

Resultaten visar att:

1. Första ovulationen pp förekom tidigare hos "normala" kor i Skeið-området, primipara kor och hos kor som kalvade i SeptemberNovember.

2. Dräktighet till första ai ökade och antal ai per dräktighet minskade med ökat antal dagar från kalvning till första ai.

3. Olika inseminationsrutiner (första ai tidig/sen) kan ge liknande resultat angående dräktighetstidpunkten.

\section{(Received June 20, 1986).}

Reprints may be requested from: J. Eldon, the Institute for Experimental Pathology, University of Iceland, Keldur, P. O. Box 8540, 128 Reykjavik, Iceland. 